\title{
PERSEPSI MAHASISWA AKUNTANSI DAN MAHASISWA HUKUM TERHADAP ETIKA PENGGELAPAN PAJAK
}

\author{
TITAH GALIH UTAMI \\ AGUS WIDODO (awd.hatta@gmail.com)
}

Fakultas Ekonomi dan Bisnis Universitas Sebelas Maret

\begin{abstract}
A B S T R A C T
This study surveyed the perception of accounting and law students in Sebelas Maret University. The two group of responden were compared to determine whether their perception were different. Populations of this research were two groups of accounting and law students in Sebelas Maret University Surakarta. A survey was constructed and distributed to group of advanced undergraduate accounting and law students. Sampling method in this survey was purposive sampling. Analysis methods were conducted to this research were pearson's correlation for validity, cronbach's alpha for reliability, one sample kolmogorov-smirnov for normalitas, and independent sample T-test for hypothesis testing. The result of this research shows that there were different perception of accounting and law students to the ethics of tax evasion. Based on the mean analysis, law students have higher scores than accounting students. This finding indicates that law students more opposed to the tax evasion than accounting students.

Keywords: perception, students, ethics, tax evasion
\end{abstract}

Penelitian ini mengamati persepsi mahasiswa akuntansi dan hukum di Universitas Sebelas Maret. Kedua kelompok responden ini dibandingkan untuk menentukan apakah persepsi mereka berbeda. Populasi dari penelitian ini adalah dua kelompok mahasiswa akuntansi dan hukum di Universitas Sebelas Maret Surakarta. Sebuah survei dibangun dan didistribusikan ke kelompok mahasiswa akuntansi dan hukum. Metode pengambilan sampel dalam survei ini dengan purposive sampling. Metode analisis yang dilakukan untuk penelitian ini adalah pearson's correlation untuk validitas, cronbach's alpha untuk reliabilitas, One Sample Kolmogorov-Smirnov untuk normalitas, dan independent sample T-test untuk pengujian hipotesis. Hasil penelitian ini menunjukkan bahwa ada persepsi yang berbeda dari mahasiswa akuntansi dan hukum untuk etika penggelapan pajak. Berdasarkan analisis rata-rata, mahasiswa hukum memiliki skor yang lebih tinggi daripada siswa akuntansi. Temuan ini menunjukkan bahwa mahasiswa hukum lebih bertentangan dengan penggelapan pajak dari siswa akuntansi.

Kata kunci: persepsi, mahasiswa, etika, penggelapan pajak

\section{PENDAHULUAN}

Menurut McGee dan Tyler (2006) permasalahan mengenai penggelapan pajak (tax evasion) menjadi penyakit akut khususnya di negara yang sedang mengalami peralihan atau perkembangan sistem ekonomi, karena mereka belum mempunyai perangkat yang memadai untuk mengumpulkan pajak. Sikap masyarakat juga merupakan faktor penting dalam pengumpulan pajak. McGee dan Tyler (2006) telah melakukan penelitian terhadap sikap wajib pajak di 33 negara seputar isu mengenai etika penggelapan pajak menurut demografi seperti gender, usia, jenjang pendidikan, dan tingkat pendapatan. Hasil dari penelitian ini menyimpulkan bahwa wanita lebih menentang pe nggelapan pajak dibanding pria, orang dengan usia lebih tua akan lebih menentang penggelapan pajak dibanding dengan yang lebih muda, orang dengan jenjang pendidikan lebih rendah lebih menentang penggelapan pajak dibanding yang mempunyai jenjang pendidikan lebih tinggi, dan orang dengan tingkat pendapatan lebih rendah lebih menentang penggelapan pajak 
daripada yang mempunyai tingkat pendapatan lebih tinggi.

Semua ahli berpendapat bahwa penggelapan pajak jelas-jelas ilegal dalam usaha mengurangi beban pajak. Penggelapan pajak adalah fenomena yang terjadi hampir di seluruh dunia, di segenap negara, dan di sepanjang masa. Tetapi toleransi terhadap penggelapan pajak berbeda-beda di setiap negara dan budaya. Crowe (1944) dalam McGee (2005b) telah mengkaji literatur ilmu ketuhanan dan ilmu filsafat yang sudah ada sejak 500 tahun dan mengidentifikasi tiga pandangan utama dalam etika penggelapan pajak yang telah berkembang selama beberapa abad. Ahli filsafat dan ahli teologi berpandangan bahwa penggelapan pajak itu (1) tidak pernah dibenarkan, (2) selalu dibenarkan, atau (3) kadang-kadang dibenarkan (McGee 2005b).

Penelitian ini dilakukan untuk mengetahi persepsi wajib pajak terhadap etika penggelapan pajak. Responden dalam penelitian ini adalah mahasiswa akuntansi dan mahasiswa hukum Universitas Sebelas Maret Surakarta. Dua kelompok ini dipilih karena di masa yang akan datang mereka akan menjadi pelaku bisnis dan pemimpin politik di Indonesia. Menurut McGee (2006) mahasiswa hukum akan lebih menentang penggelapan pajak dibandingkan mahasiswa akuntansi karena mereka diajarkan untuk lebih menghormati peraturan undang-undang.

\section{TINJAUAN PUSTAKA DAN PENGEM- BANGAN HIPOTESIS \\ Penelitian Terdahulu}

Penelitian mengenai persepsi terhadap etika penggelapan pajak telah banyak dilakukan di beberapa negara dalam kurun waktu dari tahun 2005 sampai dengan tahun 2007. McGee (2005a) melakukan penelitian terhadap mahasiswa bisnis dan staf pengajarnya di Rumania. McGee dan Ho (2006) meneliti persepsi terhadap etika penggelapan pajak pada mahasiswa akuntansi, bisnis, dan ekonomi di Hongkong. McGee dan Rossi (2006) melakukan penelitian terhadap mahasiswa hukum dan bisnis di Argentina. McGee dan
Marajyan (2006) melakukan studi empiris terhadap mahasiswa bisnis dan filsafat di Yerevan, Armenia. McGee dan Guo (2006) melakukan penelitian terhadap mahasiswa hukum, bisnis, dan filsafat di China. Nasadyuk dan McGee (2006) melakukan survey opini terhadap mahasiswa bisnis dan ekonomi di Ukraina. Pada tahun 2007, Nasadyuk dan McGee melanjutkan penelitian empiris tehadap mahasiswa bisnis dan ekonomi di Ukraina. Hasil dari penelitian yang telah dilakukan tersebut, sebagian besar responden berpandangan bahwa penggelapan pajak itu kadangkadang etis yaitu bisa etis dalam suatu keadaan dan tidak etis dalam keadaan yang lain.

\section{Penggelapan Pajak}

Semua ahli berpendapat bahwa penggelapan pajak merupakan tindakan ilegal dalam usaha mengurangi beban pajak. Penggelapan pajak adalah fenomena yang terjadi hampir di seluruh dunia. Beberapa definisi tentang penggelapan pajak dapat terlihat berikut ini (Brotohardjo 2007)

a. Harry Graham Balter: Penggelapan pajak mengandung arti sebagai usaha yang dilakukan oleh wajib pajak (apakah berhasil atau tidak) untuk mengurangi atau sama sekali menghapus utang pajak yang berdasarkan ketentuan yang berlaku sebagai pelanggaran terhadap perundang-undangan perpajakan.

b. Ernest R. Moterson: Penggelapan pajak pajak adalah usaha yang tidak dapat dibenarkan berkenaan dengan kegiatan wajib pajak untuk lari atau menghindarkan diri dari pembebanan pajak.

c. N.A. Barr, S.R. James dan A.R. Prest: Penggelapan pajak mengandung arti sebagai manipulasi secara ilegal atas penghasilannya untuk memperkecil jumlah pajak yang terutang.

d. Robert H. Anderson: Penggelapan pajak adalah penyelundupan pajak yang melanggar undang-undang pajak.

Ketentuan Umum dan Tata Cara Perpajakan pasal 38 dan pasal 39 UndangUndang No. 28 Tahun 2007, menjelaskan tentang kealpaan ataupun perbuatan dengan sengaja wajib pajak yang dapat 
menimbulkan kerugian pada pendapatan negara dan akan dikenai sanksi pidana adalah sebagai berikut:

a. tidak mendaftarkan diri atau menyalahgunakan atau menggunakan tanpa hak Nomor Pokok Wajib Pajak (NPWP).

b. tidak dapat memenuhi kewajiban menyampaikan Surat Pemberitahuan.

c. tidak dapat memenuhi kewajiban pengisian Surat Pemberitahuan dengan benar dan lengkap.

d. tidak dapat memenuhi kewajiban memelihara pembukuan dan pencatatan, termasuk tidak dapat memperlihatkan atau meminjamkan pembukuan, pencatatan dan dokumen lainnya.

e. tidak dapat memenuhi kewajiban menyetorkan pajak-pajak yang telah dipotong atau yang telah dipungut.

f. menerbitkan dan menggunakan faktur pajak, bukti pemungutan pajak, bukti pemotongan pajak, atau bukti setoran pajak yang tidak berdasarkan transaksi yang sebenarnya atau menerbitkan faktur pajak tetapi belum dikukuhkan sebagai Pengusaha Kena Pajak

\section{Persepsi}

Secara umum persepsi diartikan sebagai proses pemberian arti terhadap rangsangan yang datang dari luar. Pengertian persepsi menurut KBBI (2002) adalah tanggapan dari sesuatu atau merupakan proses seseorang mengetahui beberapa hal yang dialami oleh setiap orang dalam memahami setiap informasi tentang lingkungannya melalui panca indera. Jadi persepsi dapat diartikan sebagai proses kognitif yang dialami oleh setiap orang dalam memahami setiap informasi tentang lingkungannya melalui panca inderanya (melihat, mendengar, mencium, menyentuh, dan merasakan).

\section{Etika}

Etika secara harfiah berasal dari bahasa Yunani, yaitu ethos yang artinya sama persis dengan moralitas yaitu adat kebiasaan yang baik. Adat kebiasaan yang baik ini kemudian menjadi suatu sistem nilai yang berfungsi sebagai pedoman dan tolok ukur tingkah laku yang baik dan buruk (Keraf 1998).

\section{Pandangan Terhadap Etika Penggelapan Pajak}

Etika tentang penggelapan pajak dapat dianalisis atau dijelaskan dari beberapa perspektif yang berbeda. Beberapa diantaranya adalah dari sudut pandang ketaatan beragama, sedangkan yang lain adalah dari sudut pandang sekuler dan filsafat. Crowe (1944) dalam McGee (2005b) menggunakan tiga pendekatan berikut untuk menjelaskan etika penggelapan pajak:

1. adanya hubungan antara individu dengan negara.

2. adanya hubungan antara individu dengan anggota masyarakat sesama pembayar pajak.

3. adanya hubungan antara individu dengan Tuhan.

Dengan melalui ketiga pendekatan tersebut, Crowe mengkaji literatur teologi dan filsafat dalam 5 (lima) abad terakhir. Crowe mengidentifikasi tiga pandangan utama tentang etika penggelapan pajak yang sudah muncul selama beberapa abad. Pandangan terhadap etika penggelapan pajak tersebut adalah sebagai berikut (McGee 2005b):

1. Pandangan pertama: Tidak Pernah Etis Pandangan pertama ini adalah pandangan yang absolut yaitu bahwa penggelapan pajak "tidak pernah etis" atau tidak dibenarkan. Ada 3 (tiga) alasan utama yang mendasari pandangan ini :

a. Setiap individu mempunyai kewajiban kepada negara untuk membayar pajak apapun yang dibebankan oleh negara.

b. Setiap individu mempunyai kewajiban kepada anggota masyarakat. Setiap individu seharusnya tidak hanya mengambil manfaat dari jasa atau pelayanan negara tanpa memberikan kontribusi berupa pembayaran pajak untuk pelayanan negara tersebut. 
c. Setiap individu mempunyai kewajiban kepada Tuhan.Tuhan memerintahkan kita untuk membayar pajak kita.

\section{Pandangan kedua: Selalu Etis}

Pandangan kedua adalah pandangan bahwa penggelapan pajak itu "selalu etis" atau dibenarkan. Alasan dalam pandangan ini adalah bahwa tidak pernah ada kewajiban untuk membayar pajak karena negara selalu tidak sah (illegitimate), tidak lebih dari perampok yang tidak mempunyai moral dan otoritas untuk mengambil apapun dari siapapun.

Dalam pandangan ini tidak terdapat kontrak sosial. Dimana tidak ada persetujuan secara eksplisit untuk membayar pajak, juga tidak ada kewajiban. Semua pajak adalah mengambil kekayaan dengan paksa tanpa izin dari pemilik.

3. Pandangan ketiga: Kadang-kadang Etis Pandangan ketiga yaitu bahwa penggelapan pajak itu bisa etis dalam suatu keadaan tetapi tidak etis di keadaan yang lain. Pandangan bahwa penggelapan pajak adalah "kadang-kadang etis" merupakan pandangan yang lazim, baik dalam literatur ataupun penelitianpenelitian saat ini.

Berikut adalah beberapa literatur yang sesuai dengan ketiga pandangan tersebut (McGee 2005b):

1. Pandangan pertama: Tidak Pernah Etis

a. Cohn dan Tamari (1998)

Cohn dan Tamari menyebutkan bahwa Yahudi berpandangan bahwa penggelapan pajak itu tidak pernah etis. Menurut Cohn, perspektif Yahudi yang mendukung pembayaran pajak meliputi 4 (empat) komponen :

1) Ada kewajiban untuk mengikuti undang-undang negara.

2) Hukum akan menghalangi kebohongan.

3) Orang Yahudi seharusnya tidak melakukan hal yang menodai agama.

4) Sangat penting bagi orang Yahudi menjalankan perintah dan perbuatan sebaik mungkin, penting untuk tidak berada di dalam penjara, karena agama Yahudi tidak bisa dilaksanakan dengan baik dalam penjara.

b. DeMoville (1998)

Baha'i juga mempunyai pandangan yang tidak membenarkan penggelapan pajak, karena manusia mempunyai kewajiban untuk menuruti hukum suatu negara dimana mereka tinggal.

c. Smith dan Kimball (1998)

Beberapa kelompok umat Kristiani berpandangan bahwa penggelapan pajak itu tidak pernah etis atau tidak dapat dibenarkan. Setiap individu secara moral diwajibkan menuruti hukum negara dimana mereka tinggal.

\section{Pandangan kedua : Selalu Etis}

Tidak banyak literatur yang mendukung pandangan ini. Walaupun pandangan anarkis mendukung bahwa penggelapan pajak dapat dibenarkan atau selalu etis, mereka biasanya tidak fokus terhadap isu penggelapan pajak. Mereka biasanya cenderung mendiskusikan hubungan diantara individu dengan negara secara umum (McGee 2005b).

a. Lysander Spooner (1870)

Negara selalu tidak sah (illegitimate) dan karena itu individu tidak mempunyai kewajiban untuk mentaati undang-undang. Spooner menolak semua teori kontrak sosial dari Locke (1689), Rosseau (1762), maupun Hobbes (1651).

b. Block (1989 dan 1993)

Block telah mengkaji banyak literatur keuangan publik dan tidak dapat menemukan pembenaran untuk pembebanan pajak, walaupun dia berfikir bahwa pembenaran itu mungkin ada, hanya saja dia tidak menemukannya dalam literatur mengenai keuangan publik. Block menyimpulkan bahwa kebanyakan penulis literatur tentang keuangan publik memulai dengan asumsi bahwa pajak adalah dibenarkan oleh undang-undang dan selanjutnya mereka memulai dari itu. 
Mereka tidak pernah mengkaji ilmu filsafat yang menjadi dasar pembebanan pajak.

3. Pandangan ketiga : Kadang-kadang Etis

a. Angelus of Calvisio (1494)

Menurut Angelus, tidak ada kewajiban etis untuk membayar pajak jika pemerintah tidak menggunakan pendapatan tersebut untuk kemakmuran rakyat, setidaknya selama pemerintah tidak hanya memberikan janji palsu.

b. Crolly (1877)

Tidak ada kewajiban untuk membayar pajak jika terdapat kekerasan.

c. Berardi (1898)

Tidak ada kewajiban moral untuk membayar pajak jika terdapat kebohongan dan janji palsu, karena raja hanya mendiktekan apa yang terhutang. Pembayar pajak tidak pernah melakukan kontrak dengan raja, karena itu tidak diwajibkan untuk membayar apapun.

d. Lehmkuhl (1902)

Tidak etis menghindar dari pajak jika hal itu mengakibatkan orang lain yang tidak menghindari pajak harus melakukan pembayaran yang lebih. Dengan kata lain ada kewajiban moral untuk anggota masyrakat sesama pembayar pajak bahkan jika tidak ada kewajiban moral untuk negara.

e. Davis (1938)

Bahwa akan menjadi tidak adil untuk menharapkan atau menghendaki kejujuran pembayar pajak untuk menutup kekurangan dan membayar pajak yang lebih tinggi untuk menutup pendapatan pajak lain yang hilang karena penggelapan.

f. Genicot (1972)

Sebagian penggelapan pajak itu dapat dibenarkan dengan anggapan bahwa pemerintah tidak mempunyai hak penuh terhadap seluruh jumlah uang yang akan menyebabkan ketidakadilan yang ditimbulkan adanya pembebanan pajak yang lebih berat pada seseorang sementara orang lain hanya membayar sedikit.

g. McGee (1998)

Pandangan Islam terhadap penggelapan pajak jatuh pada kategori ini. McGee telah mengkaji literatur etika bisnis Islam dan menyimpulkan bahwa penggelapan pajak itu etis dalam kasus yang tepat, misalnya ketika pajak menyebabkan kenaikan harga (tarrif dan sales taxes) dan ketika pajak pada penghasilan, yang akan merusak insentif. Sedangkan menurut Murtuza dan Ghazanfan, mereka lebih cenderung membatasi diskusi tentang pembayaran pajak pada zakat, yaitu kewajiban yang ditujukan untuk fakir miskin.

\section{Kerangka Pemikiran}

Menurut Gibson et al. (1997), persepsi berperan dalam penerimaan rangsangan, dan menterjemahkan atau menginterpretasikan rangsangan yang sudah teratur itu untuk mempegaruhi perilaku dan membentuk sikap. Berdasarkan pendapat tersebut mencerminkan bahwa persepsi merupakan salah satu unsur psikologi yang memiliki karakteristik tertentu.

Robbin (2002) menyatakan bahwa persepsi dipengaruhi oleh faktor pelaku persepsi, faktor objek dan faktor stuasi. Kebutuhan individu yang berbeda-beda akan menimbulkan persepsi yang berbeda pula. Tekanan waktu, sikap orang lain dan faktor-faktor situasi lain juga mempengaruhi persepsi.

Atas dasar itu, persepsi mahasiswa akuntansi dan mahasiswa hukum terhadap etika penggelapan pajak bisa diterjemahkan sebagai pandangan atau penerimaan seseorang terhadap suatu peristiwa moral tertentu yaitu penggelapan pajak. Melalui proses penentuan yang kompleks berdasarkan pengalaman dan latar belakang budaya yang berbeda-beda, maka akan menimbulkan persepsi yang berlainan pula antar individu.

Melalui beberapa penjelasan di atas dapat disimpulkan bahwa konteks persepsi dalam penelitian ini, sesuai dengan penelitian sebelumnya adalah 
pandangan responden terhadap etika penggelapan pajak. Penelitian ini memfokuskan pada pendekatan yang digunakan Crowe (1944) dalam McGee (2005b) untuk mengidentifikasi pandangan wajib pajak terhadap etika penggelapan pajak. Pendekatan tersebut adalah dengan mengidentifikasi adanya hubungan antara individu dengan negara, adanya hubungan antara individu dengan masyarakat sesama pembayar pajak, dan adanya hubungan antara individu dengan Tuhan. Suatu peristiwa moral tertentu yaitu penggelapan pajak, melalui proses penentuan yang kompleks berdasarkan pengalaman dan latar belakang budaya yang berbeda-beda, maka akan menimbulkan persepsi yang berbeda pula antar individu. Dari penjelasan tersebut dapat disusun hipotesis sebagai berikut.

H1: Terdapat perbedaan persepsi antara mahasiswa akuntansi dan mahasiswa hukum terhadap etika penggelapan pajak.

\section{METODE PENELITIAN}

\section{Populasi dan Sampel}

Populasi dalam penelitian ini adalah dua kelompok responden yaitu mahasiswa akuntansi dan mahasiswa hukum Universitas Sebelas Maret Surakarta. Pengambilan sampel dilakukan menggunakan metode non probability sampling berupa purposive sampling. Dengan menggunakan metode ini diharapkan sampel yang diambil bisa representatif sesuai dengan kriteria atau spesifikasi tertentu yang telah ditetapkan sebelumnya, karena peneliti hanya akan memilih sampel yang mempunyai pengetahuan dan pemahaman tentang penggelapan pajak, sehingga mereka dapat memberikan jawaban yang dapat mendukung jalannya penelitian ini. Kriteria sampel dalam penelitian ini adalah mahasiswa akuntansi di FE UNS yang telah menempuh atau sedang menempuh mata kuliah Perencanaan Pajak dan mahasiswa hukum di FH UNS yang telah menempuh atau sedang menempuh mata kuliah Hukum Pajak. Pada mata kuliah tersebut, materi mengenai penggelapan pajak mulai diajarkan.

\section{Jenis dan Sumber Data}

Data yang dikumpulkan oleh peneliti adalah data primer, yaitu berupa tanggapan atas pertanyaan yang terdapat dalam kuesioner. Peneliti melakukan penelitian secara langsung pada lapangan. Kuesioner diberikan secara langsung pada responden, sehingga jenis penelitian tersebut termasuk dalam studi lapangan (field study).

Instrumen yang digunakan dalam penelitian ini berupa kuesioner yang terdiri dari 2 (dua) bagian. Bagian pertama dari kuesioner ini berisi pertanyaan mengenai identitas responden yang menanyakan nama, jenis kelamin, fakultas/jurusan/ semester, program studi, dan juga ditanyakan apakah pernah menempuh mata kuliah Perencanaan Pajak bagi mahasiswa akuntansi atau mata kuliah Hukum Pajak bagi mahasiswa hukum. Bagian kedua dari kuesioner berisi pernyataan mengenai etika penggelapan pajak. Pernyataan ini bersifat tertutup karena responden hanya diminta memilih alternatif jawaban yang sudah disediakan sesuai tingkat kesetujuannya.

Horizon waktu yang digunakan dalam penelitian ini adalah cross sectional study (one-shot study), yaitu datanya dikumpulkan hanya sekali dalam satu periode waktu penelitian. Cara ini diharapkan dapat mencerminkan potret suatu keadaan pada saat tertentu.

\section{Definisi Operasional dan Pengukuran Variabel}

Variabel yang akan diukur dalam penelitian ini adalah persepsi terhadap etika penggelapan pajak, dalam hal ini adalah persepsi masing-masing kelompok responden yaitu mahasiswa akuntansi dan mahasiswa hukum terhadap etika penggelapan pajak.

Variabel persepsi ini diukur dengan menggunakan skala likert 1 sampai 7. Dari pernyataan dalam kuesioner, responden diminta menjawab sesuai tingkat kesetujuannya terhadap etika penggelapan pajak. Pernyataan yang digunakan dalam penelitian ini terdiri atas 15 pernyataan negatif dengan skor 1 untuk "sangat setuju", 2 untuk "setuju", 3 untuk "sedikit setuju”, 4 untuk "netral”, 5 untuk "sedikit 
tidak setuju”, 6 untuk "tidak setuju”, dan 7 untuk "sangat tidak setuju".

\section{Metode Analisis Data}

Metode analisis data yang digunakan dalam penelitian ini diawali dengan melakukan uji validitas dan uji reliabilitas terhadap butirbutir pertanyaan yang terdapat pada kuisioner penelitian.

Uji asumsi klasik yang dilakukan dalam penelitian ini adalah uji normalitas dengan menggunakan One Sampel Kolmogorov-Smirnov Test. Jika distribusi populasi data normal, maka pengujian hipotesis dilakukan dengan menggunakan alat uji statistik parametrik, yaitu Independent Sampel T-test (Santoso 2003). Langkahlangkah pengujian berikutnya yaitu dengan melakukan F-test untuk menguji apakah varians populasi kedua kelompok sampel yaitu mahasiswa akuntansi dan mahasiswa hukum sama atau berbeda. Selanjutnya berdasarkan $F$ test, maka akan dibandingkan rata-rata kedua kelompok sampel dengan $t$ test untuk menguji hipotesis.

\section{ANALISIS DAN PEMBAHASAN \\ Pengujian Instrumen Penelitian}

Hasil uji validitas menunjukkan bahwa semua item pertanyaan yang digunakan untuk mengukur persepsi mahasiswa akuntansi dan mahasiswa hukum terhadap etika penggelapan pajak adalah valid karena besarnya probabilitas (p) pertanyaan nomor 1 sampai dengan pertanyaan nomor 15 kurang dari 0,01 .

Hasil uji reliabilitas dapat diperoleh koefisien Cronbach's Alpha sebesar 0,8922. Koefisien Alpha $>0,800$ tersebut menunjukkan bahwa tingkat reliabilitas item pertanyaan yang diajukan adalah tinggi.

\section{Pengujian Hipotesis}

Hasil pengujian normalitas yang dilakukan menunjukkan bahwa distribusi populasi data adalah normal. Berdasarkan hasil tersebut maka pengujian hipotesis dapat dilakukan dengan menggunakan alat uji statistik parametrik yaitu teknik pengujian Independent Sample T-test.
Peneliti merangkum skor dari dua kelompok responden terhadap 15 pertanyaan yang diajukan berkaitan dengan isu etika penggelapan pajak. Penilaian terhadap skor tersebut dibagi menjadi tiga kategori (1) penggelapan pajak "selalu etis" jika skor $\leq 2$, (2) penggelapan pajak "kadang-kadang etis" jika $2<$ skor $<6$, dan (3) penggelapan pajak "tidak pernah etis" jika skor $\geq 6$.

Hasil analisis data yang dilakukan menunjukkan bahwa untuk kelompok mahasiswa akuntansi, skor terhadap 15 pertanyaan jatuh pada kategori bahwa penggelapan pajak "kadang-kadang" etis. Skor untuk kelompok mahasiswa hukum, 10 pertanyaan yaitu pertanyaan nomor 110 jatuh pada kategori bahwa penggelapan pajak itu "kadang-kadang etis", sedangkan 5 pertanyaan yang lain yaitu pertanyaan nomor 11-15 jatuh pada kategori bahwa penggelapan pajak "kadang-kadang etis". Hasil analisis di atas menunjukkan bahwa (1) mahasiswa akuntansi mempunyai persepsi bahwa penggelapan pajak itu "kadang -kadang etis" dan (2) persepsi mahasiswa hukum terbagi ke dalam 2 (dua) kategori yaitu "kadang-kadang etis" dan "tidak pernah etis".

Dengan membandingkan skor antara mahasiswa akuntansi dan mahasiswa hukum menunjukkan bahwa mahasiswa hukum lebih menentang penggelapan pajak dibandingkan dengan mahasiswa akuntansi hampir di semua kasus yang ditanyakan, ditunjukkan dengan nilai skor yang lebih tinggi pada 13 dari 15 pertanyaan yaitu nomor $1,4,5,6,7,8,9,10,11,12,13,14,15$.

Alasan yang mendukung hasil bahwa mahasiswa hukum lebih menentang penggelapan pajak dibanding mahasiswa akuntansi adalah bahwa mahasiswa hukum di masa datang merupakan calon penegak hukum Indonesia. Mahasiswa hukum diajarkan untuk lebih menghormati dan patuh terhadap undang-undang.

Penggelapan pajak telah dijelaskan pula dalam Undang-Undang Perpajakan Indonesia. Dalam Ketentuan Umum dan Tata Cara Perpajakan pasal 38 dan pasal 39 Undang-Undang nomor 28 tahun 2007, dijelaskan tentang kealpaan ataupun per- 
buatan dengan sengaja wajib pajak yang dikategorikan sebagai penggelapan pajak, akan dikenai sanksi berupa surat paksa, sita, lelang, serta sanksi-sanksi pidana yang diancam dengan pidana kurungan atau penjara.

Dengan adanya undang-undang pepajakan tersebut tentu saja mahasiswa hukum dituntut untuk lebih memahami dan menghormati undang-undang untuk menegakkan undang-undang tersebut di Indonesia. Seperti pendapat McGee (2006) yaitu bahwa mahasiswa hukum akan lebih menentang penggelapan pajak, karena mahasiswa hukum diduga akan lebih menghormati undang-undang dibanding dengan mahasiswa dari disiplin ilmu yang lain.

Perbedaan persepsi yang signifikan antara mahasiswa akuntansi dan mahasiswa hukum terdapat pada pertanyaan nomor 11-15, ditunjukkan dengan nilai signifikansi $<0,05$. Pada situasi seperti pertanyaan nomor 11-15 tersebut, mahasiswa hukum berpersepsi bahwa penggelapan pajak itu "tidak pernah etis" karena melanggar hukum dan perbuatan melanggar hukum tidak pernah dibenarkan. Pada situasi dimana pemerintah sudah mempertanggung jawabkan uang hasil pengumpulan pajak secara bijaksana, serta digunakan untuk proyek yang bermanfaat bagi masyarakat, menurut mahasiswa hukum yang merupakan calon penegak hukum di Indonesia, wajib pajak tidak mempunyai alasan apapun untuk tidak mematuhi undang-undang karena pemerintah telah memberikan pelayanan yang baik bagi masyarakat.

Pada 10 pertanyaan lainnya, yaitu pertanyaan nomor 1-10 tidak terdapat perbedaan persepsi yang signifikan antara mahasiswa akuntansi dan mahasiswa hukum. Pada 10 pertanyaan tersebut mahasiswa akuntansi dan mahasiswa hukum berpersepsi bahwa penggelapan pajak itu "kadang-kadang etis". Pertanyaanpertanyaan tersebut merangkum alasan wajib pajak yang biasanya dijadikan pembenaran terhadap penggelapan pajak. Pembenaran terhadap penggelapan pajak yang telah berkembang di masyarakat selama beberapa abad tersebut telah diidentifikasi oleh Martin Crowe pada tahun 1944. Alasan yang dijadikan wajib pajak sebagai pembenaran terhadap penggelapan pajak tersebut antara lain : (1) jika pemerintah melakukan korupsi, (2) jika sistem perpajakan tidak adil, (3) jika tarif pajak terlalu tinggi, (4) jika pemerintah menindas rakyat atau pajak digunakan untuk mendukung perang, (5) jika uang yang terkumpul tidak digunakan secara bijaksana. Pada situasi tersebut, wajib pajak cenderung akan berpersepsi bahwa penggelapan pajak itu "kadang-kadang etis" artinya penggelapan pajak itu bisa dibenarkan di keadaan tertentu atau tidak dibenarkan di keadaan yang lain.

Oleh karena itu, jika pemerintah ingin mengurangi penggelapan pajak, pemerintah harus menghapus pembenaran secara moral terhadap etika penggelapan pajak yang berkembang di masyarakat. Pemerintah seharusnya tidak menindas rakyat, pemerintah seharusnya berusaha menghapus korupsi, pemerintah harus memberikan pelayanan publik yang baik sebagai ganti dari pembayaran pajak, pemerintah harus menjaga agar tarif pajak tetap rendah dan harus membagun sistem perpajakan yang adil.

Perbedaan persepsi antara mahasiswa hukum dan mahasiswa akuntansi tersebut menunjukkan bahwa persepsi wajib pajak terhadap etika penggelapan pajak akan berbeda-beda berdasarkan disiplin ilmu. Dalam penelitian-penelitian terdahulu, McGee juga menyebutkan bahwa persepsi wajib pajak terhadap etika penggelapan pajak juga akan berbeda berdasarkan latar belakang, budaya, dan demografi. Persepsi para pemilik usaha dan praktisi tentu saja juga akan berbeda dengan persepsi mahasiswa yang belum mempunyai pengalaman dan terlibat secara langsung untuk membayar pajak.

Hasil pengujian hipotesis dengan teknik Independent Sample T-test yang menghasilkan nilai signifikansi $(0,007)<$ 0,05 maka Ha diterima, artinya terdapat perbedaan persepsi yang signifikan antara mahasiswa akuntansi dan mahasiswa hukum terhadap etika penggelapan pajak. 


\section{SIMPULAN}

Berdasarkan hasil analisis data yang dilakukan yaitu dengan menggunakan analisis deskriptif dan analisis statistik yang bertujuan untuk mengetahui persepsi mahasiswa akuntansi dan mahasiswa hukum terhadap etika penggelapan pajak, dapat diambil kesimpulan bahwa mahasiswa akuntansi mempunyai persepsi bahwa penggelapan pajak itu "kadang-kadang etis". Namun didapatkan hasil yang berbeda ketika penelitian ini diujikan kepada mahasiswa hukum. Persepsi mahasiswa hukum terbagi menjadi dua kategori yaitu persepsi bahwa penggelapan pajak itu "kadang-kadang etis" dan persepsi bahwa penggelapan pajak itu "tidak pernah etis". Mahasiswa hukum mempunyai skor yang lebih tinggi hampir di semua kasus yang ditanyakan. Hasil tersebut menunjukkan bahwa mahasiswa hukum lebih menentang penggelapan pajak dibanding dengan mahasiswa akuntansi.

Menurut hasil pengujian dengan Independent Sample T-test disimpulkan bahwa terdapat perbedaan persepsi yang signifikan antara mahasiswa akuntansi dan mahasiswa hukum terhadap etika penggelapan pajak.

\section{DAFTAR PUSTAKA}

Brotodihardjo, R. S. 2003. Pengantar Ilmu Hukum Pajak. Edisi Keempat. Bandung: Refika Aditama.

Departemen Pendidikan Nasional. 2002. Kamus Besar Bahasa Indonesia. Jakarta: Balai Pustaka.

Djarwanto, P. S. 2000. Statistik Induktif. Yogyakarta: BPFE.

Gibson, J. L. 1997. Organisasi: Perilaku, Struktur, Proses (terjemahan). Jakarta: Binarupa Aksara.

Keraf, A. S. 1998. Etika Bisnis: Tuntutan dan Relevansinya. Yogyakarta: Kanisius Pustaka Filsafat.

Ludigdo, U. dan M. Machfoedz. 1999. Persepsi Akuntan dan Mahasiswa terhadap Etika Bisnis. Jurnal Riset Akuntansi Indonesia, 2 (1): 1-9.

Mardiasmo. 2006. Perpajakan. Yogyakarta: Andi.

McGee, R. W. 1994. Is Tax Evasion Unethical?. Available at: http:// papers.ssrn.com
1999. Tariffs as a Form of taxation: Is Evasion Unethical?. Journal of Accounting, Ethics, and Public Policy, 2 (2): 376-385.

2005a. The Ethics of tax Evasion: A Survey Romanian Business Students and Faculty. Available at: http://papers.ssrn.com 2005b. Three Views on the Ethical of Tax Evasion. Available at: http://papers.ssrn.com 2006a. Ethics and Tax Evasion in Asia. Available at: http:// papers.ssrn.com

McGee, R. W. dan M. J. Rossi. 2006. The Ethics of Tax Evasion: A Survey of Laws and Business Students in Argentina. Available at: http:// papers.ssrn.com

McGee, R. W. dan M. Tyler. 2006. Tax Evasion and Ethics: A Demographic Study of 33 Countries. Available at: http:// paper.ssrn.com

McGee, R. W. dan S. S. M. Ho. 2006. The Ethics of Tax Evasion: A Survey of Accounting, Business and Economic Students in Hongkong. Available at: http://papers.ssrs.com

McGee, R. W. dan T. B. Maranjayan. 2006. Tax Evasion in Armenia: An Empirical Study. Available: at http:// papers.ssrs.com

McGee, R. W. dan Z. Guo. 2006. The Ethics of Tax Evasion: A Survey of Laws, Business and Philosophy students in China. Available at: http:// papers.ssrs.com

Nasyaduk, I. dan R. W. McGee. 2006. Tax Evasion in Ukraina: A Survey of Opinion. Available at: http:// papers.ssrs.com dan 2007. Ethics and Tax evasion in Ukraina: An Empirical Study. Available at http:// papers.ssrs.com

Nugroho, B. A. 2005. Strategi Jitu Memilih Metode Statistik Penelitian dengan SPSS. Yogyakarta: Andi.

Pangestuti, E. 2008. Persepsi Mahasiswa Akuntansi Terhadap Etika Profesi Akuntan (Tidak dipublikasikan). Skripsi, Universitas Sebelas Maret, Surakarta.

Republik Indonesia. 2008. Undang-Undang Republik Indonesia Nomor 28 Tahun 2007 Tentang Perubahan Ketiga atas Undang-Undang Nomor 6 Tahun 1983 Tentang Ketentuan Umum dan 
JURNAL AKUNTANSI \& BISNIS|Vol. 15, No. 2, Agustus 2015: 96 - 105

Tata Cara Perpajakan.

Robbin, S. J. 2002. Prinsip Perilaku Organisasi (Terjemahan). Jakarta: Erlangga.

Rusli, M. A. 2005. Persepsi Akuntan, Mahasiswa Akuntansi, dan Karyawan Bagian Akuntansi Terhadap Etika Bisnis (Tidak dipublikasikan). Skripsi, Universitas Sebelas Maret, Surakarta.

Santoso, S. 2001. SPSS Versi 10: Mengolah Data Statistik Secara Profesional. Jakarta: PT Elex Media Komputindo.

Sekaran, U. 2000. Research Method for Business: A Skill Building Approach. 3ed. New York: John Wiley and Sons Inc.
Sriwahyuni dan M. Gudono. 2000. Persepsi Akuntan terhadap Kode Etik Akuntan. Jurnal Riset Akuntansi Indonesia, 3: 168-184.

Suliyanto. 2005. Metode Riset Bisnis. Yogyakarta: Andi.

Triono, A. R. 2005. Persepsi Pemakai Laporan Keuangan, Auditor, Akuntan Pendidik, dan Mahasiswa Akuntansi terhadap Expectation Gap (Dalam Isu Aturan dan Batasan Pada Kantor Akuntan Publik, Kepada Siapa Auditor Bertanggung jawab, dan Atribut Kinerja Auditor) (Tidak dipublikasikan). Skripsi, Universitas 